\title{
Does Rule of Law Affect Economic Growth Positively?
}

\author{
Aslı Ozpolat ${ }^{1}$, Gulsum Gunbala Guven ${ }^{1}$, Ferda Nakipoglu Ozsoy ${ }^{2} \&$ Ayse Bahar ${ }^{1}$ \\ ${ }^{1}$ Oguzeli Vocational School of Higher Education, University of Gaziantep, Turkey \\ ${ }^{2}$ Department of Global Politics and International Relations, Faculty of Economics \& Administrative Sciences, \\ University of Gaziantep, Turkey \\ Correspondence: Aslı Ozpolat, Asst. Prof., Oguzeli Vocational School of Higher Education, University of Gaziantep, \\ Turkey.
}

Received: June 14, 2016

Accepted: June 20, 2016

Online Published: June 22, 2016

doi:10.5430/rwe.v7n1p107

URL: http://dx.doi.org/10.5430/rwe.v7n1p107

\begin{abstract}
Efficient institutional structure resolves the uncertainties in the market and the problem of asymmetric information, and thus creates a positive exogeneity, ensures the efficient distribution of the resources and makes a positive impact on the functioning of the economy. In addition to this, especially rule of law forms the basis of the socio-economic development. In the presence of the factors such as prevention of corruption and freedom of expression, institutional structure has a significant impact on economic growth. However, there are empirical studies that state that institutional efficiency boosts economic growth in developed countries, whereas it doesn't have an impact or has a negative impact on economic growth in developing countries. For all these reasons, the impact of institutional efficiency on economic growth in developed, developing and underdeveloped countries will be analyzed in this study. In this study, the effect of institutional effectiveness on economic growth has been analyzed in both three country groups from 2002 to 2015 by using GMM. Dependent variable is GDP and the independent variables are institutional variables (rule of law, fight against corruption, voice and accountability). Based on our primitive findings we expect that developed institutions effect economic growth positively in develop countries unlike developing countries.
\end{abstract}

Keywords: institutions, institutional effectiveness, rule of law, economic growth, GMM

\section{Introduction}

North (1990) defines institutions as: "Institutions are the rules of the game in society or, more formally, are the humanly devised constraints that human interaction." In determining the rules mentioned in the definition, it is expressed that one of the most effective tools is law. The relationship between institutional structure and economy is also one of the points to be considered. Institutional structure eliminates the market distortions caused by imperfect data. Therefore, ensuring efficient decision-making of individuals and institutions by eliminating distortions is one of the significant impacts of institutional structure on economy. Institutional structure ensures that economic transactions between economic units are done in a cheaper and safer way. By this means, efficient institutional structure that increases efficiency and quality, also contributes to the development of industry and the revival of trade. Also, it may be claimed that it prevents waste of resources with the effect of reducing the inefficient use of resources by the combination of institutional stability and economical and political stability. Institutional structure contributes to economic growth by providing use of resources in productive and efficient areas (Yaprakl1, 2008: 301-317). Besides, prevention of corruption, transparency and accountability are also significant for the institutional structure to function effectively and efficiently. Rule of law principle, which is the cornerstone of rule of law and democracy, is the greatest assurance needed by people both individually and as a society. Factors like limiting the power of the state by law and protecting the individual rights and freedoms, ensuring an equal and fair environment, accepting the superiority of law over any individual create rule of law principle. Although there is not a universal consensus on the concept of "rule of law", the main principles of rule of law are defined by the Secretariat General for UN. In the 2004 report of the secretariat, it is considered within the scope of rule of law that all individuals and institutions including government agencies may be accessible and they may be held accountable under the laws consistent with the international legal norms and principles (Telli, 2014:314). It is also emphasized in the UN report that the term "rule of law" involves these principles: equality before the law, accountability to the law, fairness in the application of the law, separation of powers, participation in decision-making process, legal certainty, avoidance of arbitrariness, and procedural and legal transparency. 
Law is specific and compelling by its nature (Hafizoğulları, 2002:19). It may cause an individual to be deprived of various rights and benefits. However, it also protects an individual's rights and freedoms or economic rights and benefits from unlawful acts (Kelsen, 1951:706). Economy is the main factor which may affect the community, starting from the individuals, and even the state positively/negatively. The presence of the close relation between law and economy keeps the state standing both nationally and internationally. In this respect, the biggest danger that the state may face is the economic uncertainty. A state in such an uncertainty cannot guarantee the economic activity with laws and regulations, cannot determine the legal framework or may face a variety of strategies that may set the development of the country back (Karabacak, 2003:67). Therefore, establishing the necessary legal framework is of great significance for the development of global markets. In addition, it proves the relation between economy and law clearly that UN accepts the underlying principle of acts concerning human rights as rule of law, and that World Bank sees it as a necessary precondition of economic and social progress (Karabacak, 2003:63).

Considering rule of law with other principles like justice, equality, transparency, accountability give more accurate results in terms of implementation since these principles are not independent or irrelevant from each other. It is compulsory that the institutions meet the needs, be transparent and act in accordance with rule of law principle for a fair and equal way of behavior. Accountability is the principle whose absolute presence is needed for ensuring and sustaining rule of law principle. Fight against corruption which affects both developing and developed countries is more controllable and effective when rule of law is as it should be (Karabacak, 2003:75). Considering all these reasons, in this article, the relationship between rule of law, fight against corruption, voice and accountability and the economic growth. At this stage, countries are divided into 3 groups according to their level of development. It may be possible to identify if the relationship between the specified variables change according to the institutional development through comparison between groups. Due to the reasons mentioned above, the relationship between dimensions of governance and economic growth has been analyzed in this study. The models have been estimated using yearly data from 2002 to 2015 for country groups. Gross Domestic Product per capita has been considered as the dependent variable. The independent variables are rule of law index, control of corruption and voice and accountability. By using the variables above, relationship between the series has been analyzed with Generalized Method of Moments.

\section{Relationship between Dimensions of Governance and Economic Growth}

It is accepted in almost all relevant studies that the relationship between economy, institutional structure and rule of law has a serious place in every stage of life of individuals and the state and that this relationship is an indivisible whole. Recently, the growing population of the world indicates that the balance between the economy and law is increasingly sensitive since the level of economy affects the political state of the country seriously, and it even surpasses politics and plays a key determinant role. Since the countries with rich resources and regular economic policies are not dependent on outside financial resources, they are also comfortable in terms of human rights. It is indispensable that developing countries in the circle of poverty and with limited resources are dependent on outside financial resources, and thus are exposed to strict economic programs. Public opposition emerging in time sometimes ignores the law and prepares the ground for negative enforcements (Çeçen, 1989:526). Especially in such cases, it can clearly be seen that there is a very close relationship between economy and rule of law.

In communities in which the law is superior and which is in safety and peace, since the economic rights are guaranteed, development and growth gains momentum. Nationally, processes such as protection of property rights or creation of capital markets are factors affecting the economic development, and also creation of a favorable environment for foreign investors is necessary for creating an economic growth in the legal platform. Similarly, freedom of expression, accountability and prevention of corruption are also significant variables for economic growth to take place and to be sustainable. These components of institutional structure affect economy in several different ways. Firstly, increase in prosperity raises the demand of higher quality institutions (transparency and accountability). Secondly, high increase in prosperity makes the institutions more affordable. Lastly, economic development is new agence of change and creates the demand of new institutions (Chang, 2010:476). Acemoğlu, Johnson and Robinson (2005), relates the effect of institutional structure on economy with 3 institutional characteristics; economic institutions, political power and political institutions. The process of these institutional characteristics' effect on economy is given in Figure 1. 


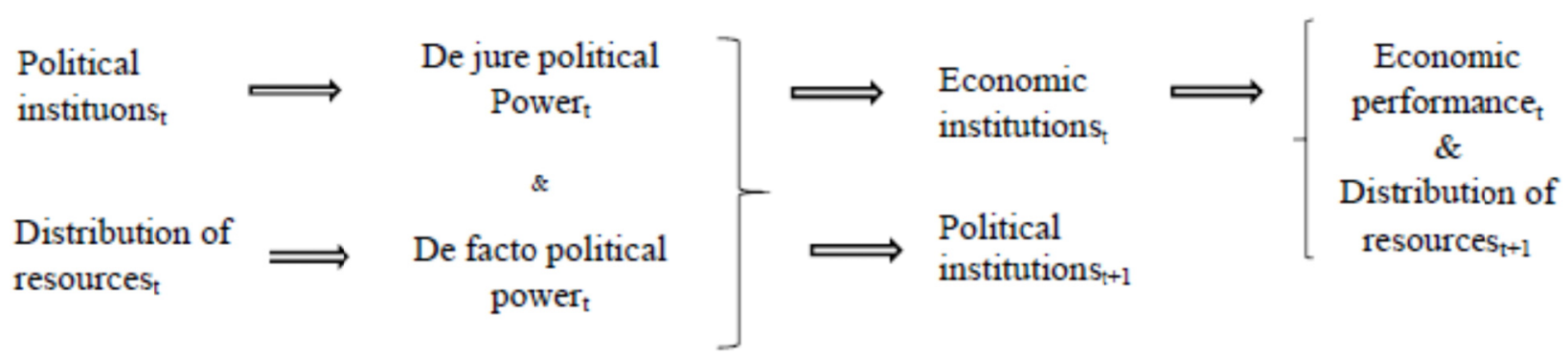

Figure 1. The framework of relationship between institutions and economy (Acemoğlu et al.:2005)

According to Figure 1, institutional factors occuring in a period has an effect on the economic performance of the same period, and they also affect the distribution of resources in the following period. However, when the historical processes of countries are studied, this interaction process gives us only a partial picture of the currently dominant discourse on institutions and development (Chang, 2010:477).

Rule of law index may be considered as a contribution to the relationship between law and economy. World Rule of Law Index calculates rule of law index interviewing with 100.000 individuals and 3000 experts for countries. Index evaluates rule of law considering 8 sub-topics. These are stated as limitation of state power, the presence of corruption, open state, fundamental rights, order and safety, regulatory practices, personal judgment and criminal justice. Institutional Indicators components are stated as follows (Kaufmann et al., 2010:3):

- Voice and Accountability (VA): Political participation, freedom of expression, freedom of association, and a free media.

- Political Stability and Absence of Violence/Terrorism (PV): government stability, politically-motivated violence and terrorism.

- Government Effectiveness (GE): the quality of public services, the quality of the civil service and the degree of its independence, the quality of policy formulation and implementation.

- $\quad$ Regulatory Quality (RQ): to formulate and implement sound policies and regulations that permit and promote private sector development.

- Rule of Law (RL): confidence on the rules of society, law and order, the efficeny of judicial system, the quality of contract enforcement, property rights and trust to the police, and the courts.

- Control of Corruption (CC): public power is exercised for private gain, including forms of corruption.

In Table 1, 2015 World Rule of Law Index is shown. In the index, there are 99 countries in 2014, and 102 countries in 2015 .

Table 1. Rule of law index 2014 and 2015 for selected countries (WJP, 2015)

\begin{tabular}{|c|c|c|c|c|}
\hline \multirow[t]{2}{*}{ Countries } & \multicolumn{2}{|c|}{2014} & \multicolumn{2}{|c|}{2015} \\
\hline & Rank & Score & Rank & Score \\
\hline Denmark & 1 & 0.88 & 1 & 0.87 \\
\hline Norway & 2 & 0.88 & 2 & 0.87 \\
\hline Sweden & 3 & 0.85 & 3 & 0.85 \\
\hline Finland & 4 & 0.84 & 4 & 0.85 \\
\hline Canada & 11 & 0.78 & 14 & 0.78 \\
\hline France & 18 & 0.74 & 18 & 0.74 \\
\hline United States & 19 & 0.71 & 19 & 0.73 \\
\hline Uruguay & 20 & 0.69 & 22 & 0.71 \\
\hline Italy & 29 & 0.63 & 30 & 0.64 \\
\hline
\end{tabular}




\begin{tabular}{cllll}
\hline \hline Greece & 32 & 0.59 & 33 & 0.60 \\
Bulgaria & 44 & 0.53 & 45 & 0.55 \\
Jamaica & 45 & 0.53 & 42 & 0.56 \\
Panama & 56 & 0.50 & 49 & 0.53 \\
Argentina & 58 & 0.50 & 54 & 0.52 \\
Turkey & 59 & 0.50 & 80 & 0.46 \\
China & 76 & 0.45 & 71 & 0.48 \\
Mexico & 79 & 0.45 & 79 & 0.47 \\
Russia & 80 & 0.45 & 75 & 0.47 \\
Iran & 82 & 0.44 & 88 & 0.43 \\
Venezuela & 99 & 0.31 & 102 & 0.31 \\
\hline
\end{tabular}

According to this, when the countries in Table 1 are analyzed, it can be seen that the most serious change is in Turkey. While some of the other countries are in the same place in the list and have the same scores, some of them has slight changes. However, in 2015, Turkey has a serious regress in the range, and became the $81^{\text {st }}$ in 102 countries, 21 ranges back compared to the previous year. The reasons of this regress may be divided into two categories; political and economical. The problems in terms of politics may be stated as political differences, increasing terrorist attacks and losses, the presence of security gap, corruption claims and ignorance of rule of law principle. And the problems in terms of economy may be stated as the increasing level of unemployment, the decrease in income levels, inequality in income and immigration. Among the countries in Table 1, China makes a difference in terms of progress. It has a 0,03 points progress compared to the previous year that makes it $71^{\text {st }}$ in the range. Venezuela is the last country in the range among 99 countries in 2014, and it is the last country among 102 countries in 2015 (World Justice Project: Rule of Law Index 2015).

In Figure 2, the comparative values of GDP per capita, rule of law index, control of corruption index and voice and accountability index for countries with high, middle and low income economies can be seen. Canada and France which are in the high income group are at the top in all index values. The more income levels increase, the more index value increases or stays the same. It can be seen that the index values are close to each other and at a low range in countries which are in middle income and low income groups such as Turkey, China, Greece and Bulgaria. Especially in Greece, the lower the income level is, the more rule of law index decreases.

Canada

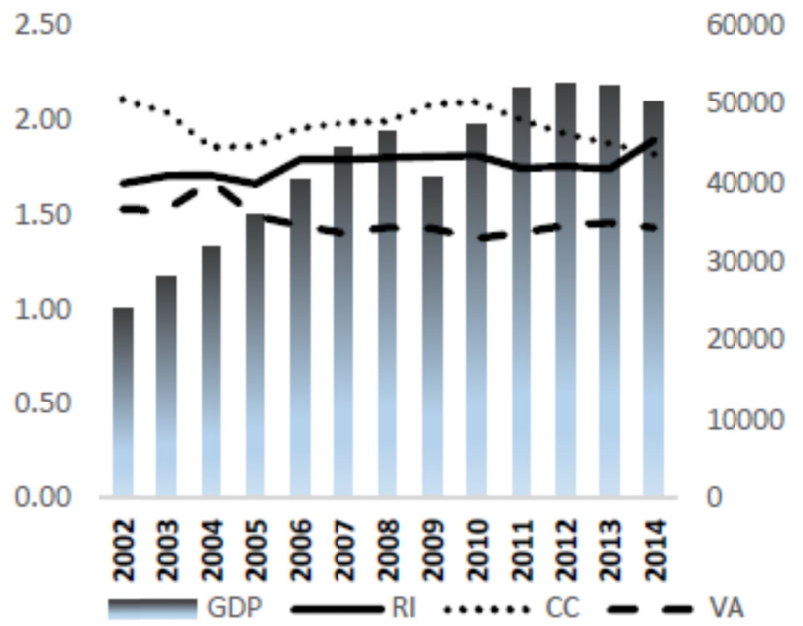

France

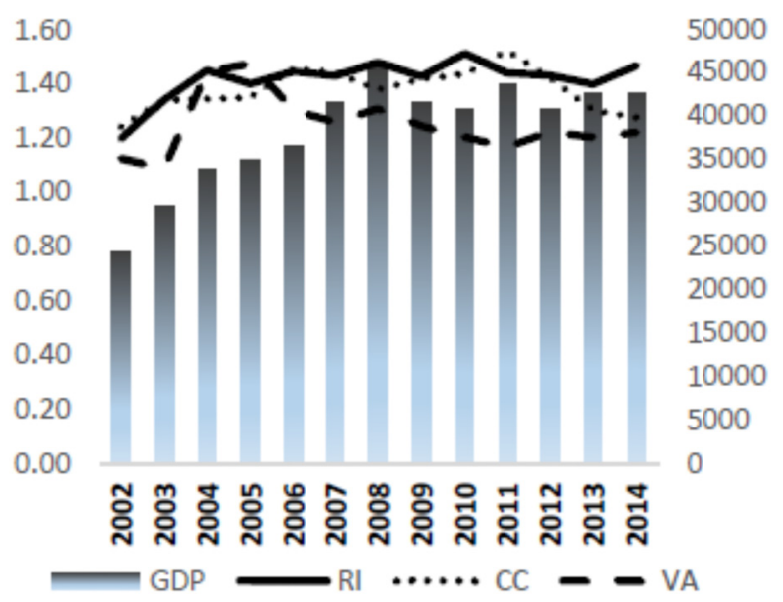




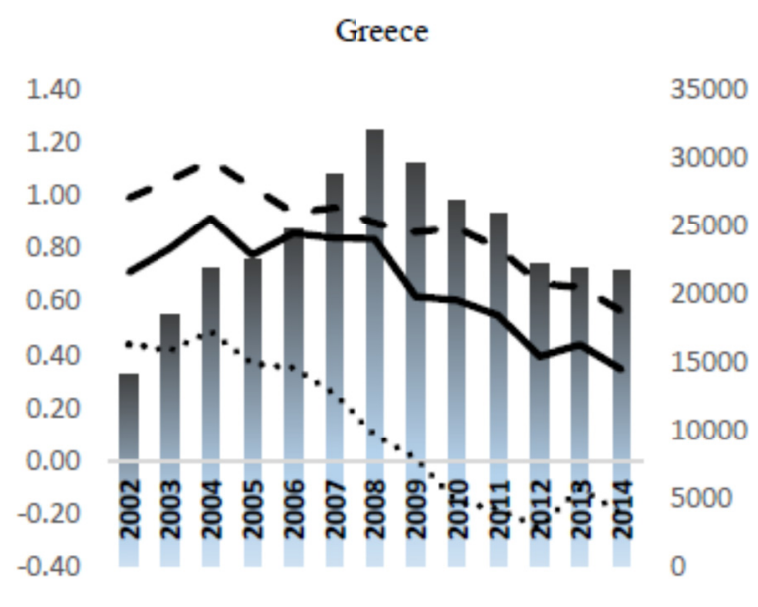

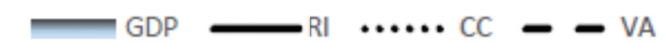

Turkey

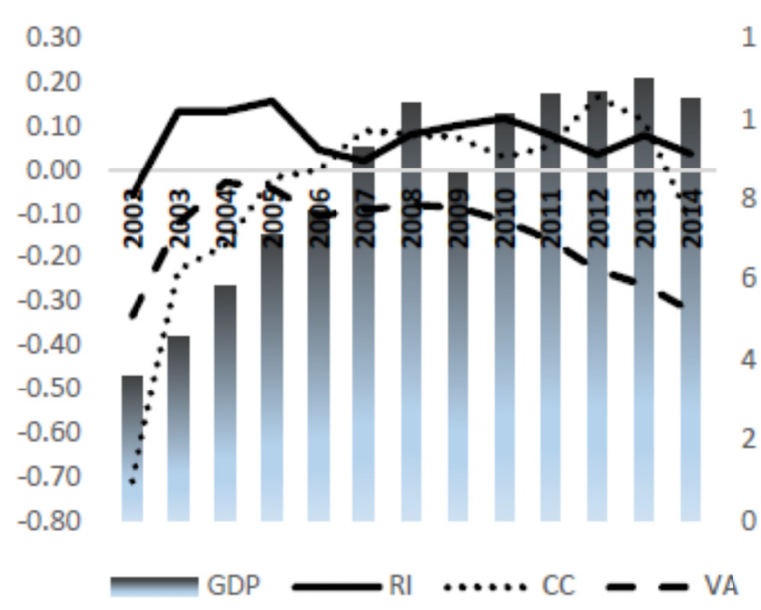

Bulgaria

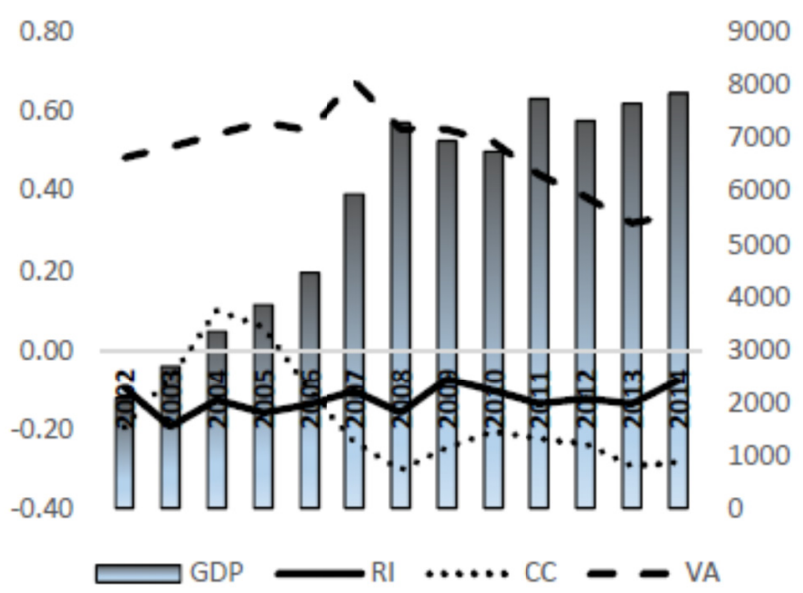

China

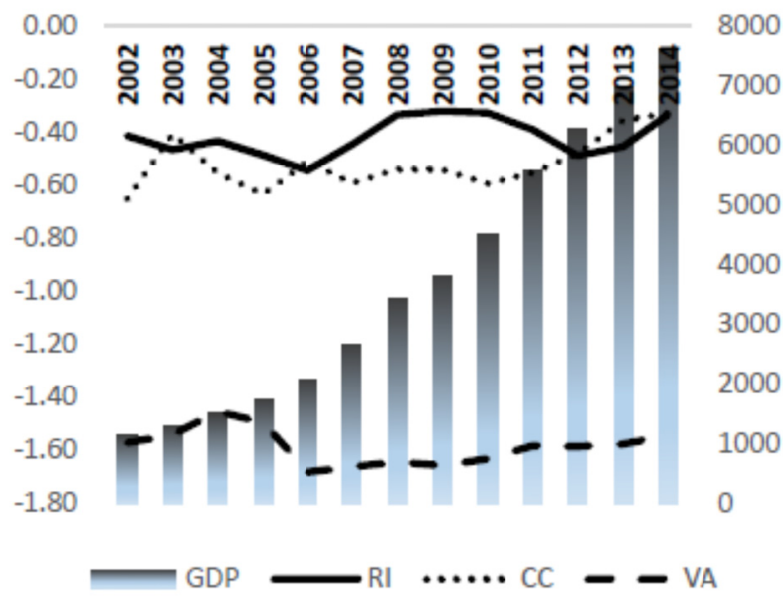

Figure 2. Economic growth and dimensions of governance for selected countries (WJP, 2015)

There are several studies on the relationship between institutional structure and its characteristics and economy. These studies change according to the income status, institutional structure and economical performance of the countries. In the study that Kaufmann, Kraay and Zoido-Lobaton (1999) did for 150 countries, they found out that there is a serious cause and effect relationship between rule of law and income per capita, literacy and infant mortality rate. And income per capita gap may be 3 times more in the countries not implementing rule of law principle compared to the countries implementing it.

Nobel-winning economist North (1990), who believes that short-term economic growth is possible without the requirement of the rule of law, argues that to provide long-term economic growth especially in dictatorial regimes, development in rule of law issues is required since North and Thomas (1973) states that lack of protection of property rights prevents capital investments which would help economic growth. Furthermore, Knack and Keefer (1995: 207-227) and Hall and Jones (1999: 83-116) claim that there is a close and positive relationship between property rights and economic growth. Protecting property rights and taking them under the state guarantee and thus the increase in investment demand affect the economic growth positively as it is in technological and other various innovations. Knack thinks that it is possible to prevent macroeconomic instabilities this way (1999:185-211). In their study covering the years 1950-2009, Valeriani and Peluso (2011) made a panel data analysis for 181 developed and developing countries. As a result of the analysis, they stated that institutional quality has a positive effect on economic growth in developed and developing countries. Thus, generally, it can be concluded that with the increase of rule of law in a country, social welfare and per capita income increases seriously in that country. However, there are studies stating that the positive effect of institutional structure on economic growth is only possible in developed 
countries. In this respect, Yapraklı (2008), in his panel data study for 36 middle income countries, found a negative relationship between components of institutional structure and economic growth. Londregan and Poole (1990), in their study for 121 countries between the years 1950-1982, used the variables population, income per capita, riots, failed coups, successful coups, elections, political executions and deaths due to domestic political violence and couldn't find a direct relationship between income and the stated variables. Bienen et al. (1993), Sachs and Warner (1997), in their study for African countries, stated that the slow growth in Africa is caused by natural causes such as limited access to the sea, abundance of natural resources, and tropical climate. Besides, in the study, they concluded that basic economical policies like being open to international trade, government saving and market-supporting institutions have a significant effect on economic growth. Helliwell (1992) studied the relationship between democracy and economic growth in his study for 125 countries. In the study, he concluded that there is a positive relationship between democracy and economic growth countries in high income countries, yet he claims that democracy has a negative but insignificant effect on growth in countries in low income countries. Doucouliagos and Ulubaşoğlu (2008), in their study on 84 countries, concluded that there is not a relationship between democracy and economic growth. As a result of the study for 145 countries grouped as high income, middle income and low income. Fabro and Aixala (2009) found that institutional quality stimulates economic growth only in high income and middle income countries. Ata, Koç and Akça (2012), in their study on 30 OECD countries, found a positive and statistically meaningful results about the relationship between accountability and rule of law and economic growth whereas they couldn't find a direct relationship between regulatory quality, prevention of corruption and economic growth. However, in the studies of Alesina and Perotti (1994); Alesina and Rodrik (1994); Alesina et al. (1996); Chong and Calderon (2000) and Chang (2003), results show that institutional structure is not as effective as it is in developed countries and that institutions have a negative effect on growth. In Table 2, there are some of the studies on the relationship between institutional structure and economic growth.

Table 2. Studies on the relationship between institutional structure and economic growth

\begin{tabular}{|c|c|c|c|}
\hline Authors & Year & Country Group & Result \\
\hline Scully (1988) & $1960-1980$ & 115 market economies & $\begin{array}{l}\text { Institutional structure has a } \\
\text { meaningful and significant effect on } \\
\text { the rate and efficiency of economic } \\
\text { growth. }\end{array}$ \\
\hline $\begin{array}{l}\text { Alberto, et al. } \\
\text { (1996) }\end{array}$ & $1950-1982$ & 113 countries & $\begin{array}{l}\text { The effect of democratic institutions is } \\
\text { not found statistically significant }\end{array}$ \\
\hline $\begin{array}{l}\text { Ali and Crain } \\
(2002)\end{array}$ & 1975-1989 & 119 countries & $\begin{array}{l}\text { Different from economic freedom, } \\
\text { political regimes and civil freedom is } \\
\text { not seen significant for growth. Civil } \\
\text { freedom level and political regimes } \\
\text { are not necessary for the infrastructure } \\
\text { of the national economy. }\end{array}$ \\
\hline $\begin{array}{l}\text { Fabro and Aixalá } \\
(2009)\end{array}$ & $1996-2000$ & 145 countries & $\begin{array}{l}\text { While institutional quality variable is } \\
\text { not sufficient for explaining economic } \\
\text { development level of poor countries, it } \\
\text { has quite a significant effect on } \\
\text { explaining economic development } \\
\text { level of high income countries since it } \\
\text { is necessary for institutional quality } \\
\text { level to be over a specific limit. }\end{array}$ \\
\hline $\begin{array}{l}\text { Valeriani and } \\
\text { Peluso (2011) }\end{array}$ & $1950-2009$ & 181 countries & $\begin{array}{l}\text { Institutional quality has a positive } \\
\text { effect on economic growth. The size } \\
\text { of the effect differs when it is } \\
\text { considered in terms of developed and } \\
\text { developing countries. }\end{array}$ \\
\hline
\end{tabular}




\begin{tabular}{|c|c|c|c|}
\hline $\begin{array}{l}\text { Willianson and } \\
\text { Mathers (2011) }\end{array}$ & 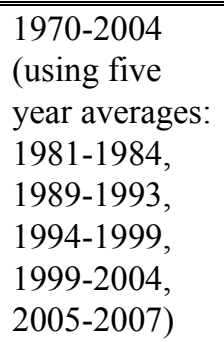 & 141 countries & $\begin{array}{l}\text { Culture and economic freedom are } \\
\text { recognized as important for economic } \\
\text { growth. However, economic freedom } \\
\text { is relatively more important for } \\
\text { growth than culture. }\end{array}$ \\
\hline Ata, et al. (2012) & 2009 & 30 OECD countries & $\begin{array}{l}\text { Accountability and the rule of law } \\
\text { have a statistically significant and } \\
\text { positive effect on economic growth. } \\
\text { However, there is no significant } \\
\text { interaction between the institutional } \\
\text { structure and economic growth. }\end{array}$ \\
\hline
\end{tabular}

\section{Data and Methodology}

As regards to the data employed in this study, the annual data is collected for the period 2002-2015 for the country groups. Country groups are classified according to World Justice Project report in 2015. Each country group includes 20 countries.

The variables used in this study covers real gross domestic product per capita (GDP) in billions of constant 2005 US $\$$, rule of law index, control of corruption index and voice and accountability index. The data of real (GDP) per capita is sourced from World Development Indicators 2015 (World Bank), and rule of law index, control of corruption index and voice and accountability index is sourced from The Worldwide Governance Indicators 2015. All variables are in natural logarithms.

The Model is written as follows:

$$
\operatorname{In} y_{t, i}=\beta_{0}+\beta_{1} \operatorname{InC} C_{t, i}+\beta_{3} \operatorname{InR} I_{t, i}+\beta_{4} \operatorname{In} V A_{t, i}+\varepsilon
$$

Where:

Y: Reel Gross Domestic Product

RI: Rule of Law Index

CC: Control of Corruption Index

VA: Voice and Accountability Index

Analysis will be estimated by using Generalized Method of Moments (GMM). OLS estimator and GLS estimator may give biased results in estimating dynamic panel data sets. For this reason, Arrellano and Bond (1991) developed Generalized Method of Moments model which is a more effective method. In this method, first order differences of dynamic panel data analysis variables are taken, and past values for dependent variables are used as instrumental variable (Baltagi, 2001:130-131). The model developed by Arrellano and Bond (1981) is defined as One-step and Two-step. In One-step model, error term doesn't have a serial correlation and has a homoscedastic characteristic. Explanatory variables are uncorrelated with the effect particular to groups in unobservable panel. One-step model is formulated as follows:

$$
\begin{aligned}
& \left.\hat{\delta}_{1}=\left[\begin{array}{llllll}
\left(\Delta y_{-1}\right) ' W & (W & \left(I_{N}\right. & \times & G
\end{array}\right) W\right)^{-1} W \\
& x[
\end{aligned}
$$

In the event that error term is heteroscedastic, two-stage GMM estimator is suggested. In the first stage of estimation, it is assumed that error terms are homoscedastic against time with independent and explanatory variables. Two-step GMM is formulated as follows:

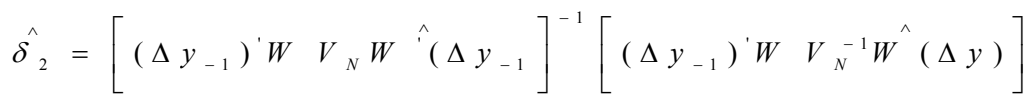

This GMM estimator does not require knowledge related to the first conditions or the distribution of $v_{i}$ and $\mu_{i}$. To make this estimator functional, $\Delta v$ is replaced by differentiated residuals obtained from the estimator $\delta_{1}$. 


\section{Empirical Results}

In the article, the relationship between rule of law, control of corruption, voice and accountability and economic growth is studied. Country groups are classified according to their income and development levels by World Bank Justice Project. The countries in the first group are in the upper levels in the range in terms of both income and development. Whereas the countries in the second group have a mid-level development in the range, the countries in the third group are at the bottom of the range.

GMM analysis is used for 3 country groups classified according to their development level. The purpose of classifying countries according to their development levels is to determine if institutional variables are related to the development level of the countries.

\subsection{First Group Countries}

Countries in the high income level are as follows: Australia, Belgium, Canada, Denmark, France, Finland, Germany, Japan, Korea, Norway, Netherlands, Sweden, Singapore, Poland, Portugal, Spain, the United Kingdom, the United States and Italy. According to that, the estimation results are plotted in Table 3.

Table 3. GMM results for high income countries

\begin{tabular}{ccccr}
\hline Variable & Coefficient & Std. Error & t-Statistic & Prob. \\
\hline CC & 0.038210 & 0.013372 & 2.857570 & 0.0047 \\
RI & 0.047394 & 0.018714 & 2.532550 & 0.0121 \\
VA & 0.028874 & 0.006695 & 4.312755 & 0.0021 \\
\hline
\end{tabular}

As a result of the model for high income countries, development of institutional structure in developed countries have a positive effect on economic growth. Considering the statistically meaningful results, a $1 \%$ increase in control of corruption increases income per capita by $\% 0,03$. Similarly, a $\% 1$ increase in rule of law increases income per capita by $0,04 \%$, and a $1 \%$ increase in voice and accountability increases income per capita by $0,02 \%$.

\subsection{Second Group Countries}

The countries in this group are as follows: Ghana, Croatia, Hungary, Senegal, Malaysia, Bosnia, Jordan, Jamaica, Tunisia, Macedonia, Bulgaria, Nepal, Belarus, Philippine, Indonesia, Albania, Argentina, Thaliand, Panama, Greece. According to that, the estimation results are in Table 4.

Table 4. GMM results for middle income countries

\begin{tabular}{ccccc}
\hline Variable & Coefficient & Std. Error & t-Statistic & Prob. \\
\hline CC & 0.005236 & 0.117679 & 0.044496 & 0.9646 \\
RI & 0.026593 & 0.080427 & 0.330643 & 0.7412 \\
VA & 0.030144 & 0.059826 & 0.503853 & 0.6149 \\
\hline
\end{tabular}

As a result of the model, the values obtained are not statistically meaningful. Considering the results in general, in countries whose institutional structure is not at a specific level, institutional variables do not have an effect on economic development.

\subsection{Third Group Countries}

The countries in this group are as follows: Kirghizstan, Zimbabwe, Cambodia, Pakistan, Cameron, Nigeria, Uganda, Bolivia, Bangladesh, Ethiopia, Iran, Egypt, Turkey, Russia, China, Ukraine, Moldova, Mexico, Lebanon, Belize. According to that, the estimation results are in Table 5. 
Table 5. GMM results for low income countries

\begin{tabular}{crrrr}
\hline Variable & Coefficient & Std. Error & t-Statistic & Prob. \\
\hline CC & 0.122397 & 0.127378 & 0.960895 & 0.3379 \\
RI & 0.017933 & 0.065014 & 0.275832 & 0.7830 \\
VA & -0.089481 & 0.181960 & -0.491758 & 0.6235 \\
& & & & \\
\hline
\end{tabular}

Similar to the results of the countries in the second group, the results obtained in this group are not meaningful. Therefore, in countries whose income level and institutional structure are not developed, institutional variables do not have an effect on growth.

\section{Conclusion}

According to the view arguing that economics depends on institutions not on individuals, efficient institutional structure solves the problem of market uncertainties and asymmetric information, creates positive exogeneity, and provides an efficient distribution of the resources. Institutional structure involves significant factors such as rule of law, control of corruption, freedom of expression, political stability, quality of bureaucracy and guaranteeing property rights. These factors increase reliability of economy especially in developed countries and attract investments, and increases economic growth. Besides this, institutional factors are substantially effective in eliminating the unfair distribution of income. However, there are empirical studies claiming that institutional efficiency increases economic growth in developed countries, and has no effect or negative effect in developing countries. Therefore, it can be stated that institutional efficiency is not a reason of growth but a result of it.

Considering these reasons, in this study, the effect of institutional efficiency on economic growth in developed, developing and under-developed countries is analyzed. With the data obtained from the countries classified according to their development levels, the relationship between institutional structure and economic growth is clearly revealed.

In this paper, the relationship between dimensions of governance and economic growth for 2002-2015 in high income, middle income and low income countries has been investigated. The empirical results show that rule of law index, control of corruption index and voice and accountability index are positively correlated with GDP in high income countries. On the other hand, as a result of the studies on developing and under-developed countries, the results are not statistically meaningful. The results obtained in this study coincide with the results obtained by Fabro and Aixalá (2009); Valeriani and Peluso (2011), Londregan and Poole (1990); Bienen et al. (1993); Sachs and Warner (1997). Fabro and Aixalá (2009) have found evidence that institutional quality variable is not sufficient for level of poor countries. Besides, institutional quality has quite a significant effect on high income countries. While institutional quality has a positive effect on economic growth, it shows different size of effect on developed and developing countries in the results of Valeriani and Peluso (2011). Londregan and Poole (1990); Bienen et al. (1993) and; Sachs and Warner (1997) also have found evidence that supports our result.

In this study, it tries to respond to questions about whether or not the positive relationship between rule of law and economic growth in terms of high income, middle income and low income countries. The evidence suggests that this relation is not relevant to explain the level of economic development of the middle income and low income countries. In the light of the data obtained from the analysis, it can be stated that the efficiency of institutional structure is not a reason but a result of growth.

\section{References}

Acemoğlu, D., \& Robinson, D. (2005). The Role of Institutions in Growth and Development. Commission on Growth and Development Working Paper No:10, pp. 1-44.

Alberto, A., Ozler, S., Roubini, N., \& Swagel, P. (1996). Political Instability and Economic Growth. Journal of Economic Growth, 1(2), 189-211, http://dx.doi.org/10.1007/BF00138862

Alesina, A., \& Perotti, R. (1994). The Political Economy of Growth: A Critical Survey of the Recent Literature. The World Bank Economic Review, 8(3), 351-71. http://dx.doi.org/10.1093/wber/8.3.351 
Alesina, A., \& Rodrik, D. (1994). Distributive Politics and Economic Growth. Quarterly Journal of Economics, (109), 465-90. http://dx.doi.org/10.2307/2118470

Alesina, A., Ozler, Ġ., Roubini, N., \& Swagel, P. (1996). Political Instability and Economic Growth. Journal of Economic Growth, 1(2), 189-211. http://dx.doi.org/10.1007/BF00138862

Ali, A. M., \& Crain, W. M. (2002). Institutional Distortions, Economic Freedom, and Growth. Cato Journal, 21(3), 415-426.

Arellano, Manuel, \& Bond, Stephen. (1991). Some Tests of Specification for Panel Data: Monte Carlo Evidence and an Application to Employment Equations. Review of Economic Studies, 58(2), 277-297. http://dx.doi.org/10.2307/2297968

Ata, A.Y., Koc, A., \& Akca, H. (2012). The Relationship Between Economic Growth and Institutional Structure in OECD Countries: Cross Sectional Analysis. Actual Problems of Economics, 10(136), 323-333.

Baltagi, B. (2001). Econometric Analysis of Panel Data. John Wiley and Sons LTD, New York.

Bienen, H.S., Londrcgan, J., \& Van De Wallc, N. (1993). Ethnicity, Leadership Succession, and Economic Development in Africa. Institute for Policy Reform, Washington, D.C.

Çeçen, A. (1989). Ekonomi ve İnsan Hakları. Türkiye Barolar Birliği Dergisi, (4), 526.

Chang, H.J. (2010). Institutions and Economic Development: Theory, Policy and History. Journal of Institutional Economics, 7(4), 473-498.

Chong, A., \& Calderon, C. (2000). Causality and Feedback between Institutional Measures and Economic Growth. Economics and Politics, 12(1), 69-82.

Doucouliagos, C.H., \& Ulubasoglu, M.A. (2004). Institutions and Economic Growth: A Systems Approach. Econometric Society 2004 Australasian Meetings No: 63, pp. 1-33.

Fabro, G., \& Aixalá, J. (2009). Economic Growth and Institutional Quality: Global and Income-Level Analyses. Journal of Economic Issues, 43(4), 997-1023. http://dx.doi.org/10.2753/JEI0021-3624430409

Hafizogullari, Z. (2002). Türk Hukuk Düzeninde Hukukun Üstünlüğü Prensibi Sorunu. Ankara Barosu Dergisi, (1), 15-33.

Hall, R.E., \& Jones, C.I. (1999). Why Do Some Country Produce So Much More Output Per Worker than Others?, Quarterly Journal of Economics, 114(1), 83-116. http://dx.doi.org/10.1162/003355399555954

Helliwell, J. (1992). Empirical Linkages between Democracy and Economic Growth. NBER Working Papers Series, Working Paper No. 4066, pp. 1-35.

Karabacak, H. (2003). Hukukun Üstünlüğü ve İyi Yönetişim, İyi Yönetişimin Temel Unsurları, Maliye Bakanlığı Avrupa Birliği ve Dış İlişkiler Dairesi Başkanlığı Yayınları, Ankara pp. 63-75. Retrieved from http://www.abmaliye.gov.tr/Sayfalar/Kitaplar.aspx

Kaufmann, D., Kraay, A., \& Mastruzzi, M. (2010). The Worldwide Governance Indicators: Methodology and Analytical Issues. Global Economy and Development. Retrieved from http://www.brookings.edu/ /media/research/files/reports/2010/9/wgi\%20kaufmann/09_wgi_kaufmann.pdf

Kaufmann, D., Kraay, A., \& Zoido Lobaton, P. (1999). Governance Matters. Policy Research Working Paper 2196.

Kelsen, H. (1951). The Law of the United Nations: A Critical Analysis of Its Fundamental Problems. Steven and Sons Limited, London, p. 706.

Knack, S. (1999). Institutions and Economic Performance; Property Rights and Contract Enforcement. Journal of Economic Growth, (4), 185-211.

Knack, S., \& Keefer, P. (1995). Institutions and Economic Performance: Cross Country Test Using Alternative Measures. Economic and Politics, (7), 207-227. http://dx.doi.org/10.1111/j.1468-0343.1995.tb00111.x

Londregan, J., \& Poole, K. (1990). Poverty, die Coup Trap, and the Seizure of Executive Power. World Politics, 42(2), 151-83. http://dx.doi.org/10.2307/2010462

North, D.C. (1990). Institutions, Institutional Change, and Economic Performance. New York: Cambridge University Press. http://dx.doi.org/10.1017/CBO9780511808678 
North, D.C., \& Thomas, R.P. (1973). The Rise of the Western World: A New Economic History. Cambridge: Cambridge University Press. http://dx.doi.org/10.1017/CBO9780511819438

Sachs, J. D., \& Warner, A.M. (1997). Sources of Slow Growth in African Economies. Journal of African Economies, 6(3), 335-76. http://dx.doi.org/10.1093/oxfordjournals.jae.a020932

Scully, G. W. (1988). The Institutional Framework and Economic Development. Journal of Political Economy, 96(3), 652-662.

Telli, K. (2014). Birleşmiş Milletler 2015. Sonrası Kalkınma Gündemi ve Hukukun Üstünlüğü Illişkisi, 4(72), 314.

Valeriani, E., \& Peluso, S. (2011). The Impact of Institutional Quality on Economic Growth and Development: An Empirical Study. Journal of Knowledge Management, Economics and Information Technology, 6, 1-25.

Willianson, C. R., \& Mathers, R. L. (2011). Economic Freedom, Culture, and Growth. Public Choice, 148(3/4), 313-335. http://dx.doi.org/10.1007/s11127-010-9656-z

World Justice Project. (2015). Rule of Law Index 2015. Retrieved from http://worldjusticeproject.org/sites/default/files/roli_2015_0.pdf

Yapraklı, S. (2008). Kurumsal Yapının Ekonomik Büyümeye Etkisi: Üst Orta Gelir Düzeyindeki Ülkeler Üzerine Bir Uygulama. Ege Akademik Bakış, 8(1), 303-319. 